\title{
Risk Factors of Laryngeal Carcinoma in Otorhinolaryngology-Head and Neck Division of Dr. Hasan Sadikin Hospital Bandung
}

\author{
Sarah A Putri*, Yussy A Dewi**, Birgitta M Dewayani*** \\ *Faculty of Medicine Padjadjaran University \\ **Department of Otorhinolaryngology-Head and Neck \\ Faculty of Medicine Padjadjaran University - Dr. Hasan Sadikin General Hospital \\ ***Department of Anatomical Pathology \\ Faculty of Medicine Padjadjaran University - Dr. Hasan Sadikin General Hospital \\ Jl. Prof. Eyckman No. 38, Bandung, 40161 \\ Email: sarah.anjaniputri@gmail.com
}

\begin{abstract}
Laryngeal carcinoma is squamous cell malignancy of larynx epithelial. In Indonesia, the incidence is 2 per 100,000 men and 0.2 per 100,000 women. The risk factors of laryngeal carcinoma include age, sex, family history, smoking habit, alcohol drink, and gastroesophangeal reflux disease (GERD)/ laryngopharyngeal reflux (LPR). This study aims to observe laryngeal carcinoma risk factors in Dr. Hasan Sadikin Hospital, Bandung. Hospitalbased unmatched case control study is selected as the method, involving 80 patients in Oncology Clinic of Otorhinolaryngology-Head and Neck Surgery Department, Dr. HasanSadikin General Hospital. This study shows that age percentage of 50-79 years old in the case group is $82.5 \%$ (OR 7.29). Male respondents dominate the case group (90\%) (OR 6.00). Respondents with GERD in the case group is 45\% (OR 15.54, p<0.005). The other analyzed variables, such as family history, smoking history, and alcohol consumption are statistically insignificant. This study shows that the results of age, sex, and GERD/LPR are corresponding with the results with previous studies. However, the results of smoking, alcohol, and family history are not. Therefore, old age, male sex, and GERD increase the risk of having laryngeal carcinoma.
\end{abstract}

Keywords : risk factors, laryngeal carcinoma 


\title{
Faktor Risiko Karsinoma Laring di Bagian THT-KL Rumah Sakit Dr. Hasan Sadikin Bandung
}

\author{
Sarah A Putri*, Yussy A Dewi**, Birgitta M Dewayani**** \\ * Fakultas Kedokteran Universitas Padjadjaran \\ ** Departemen Telinga-Hidung-Tenggorok Kepala-Leher \\ Fakultas Kedokteran Universitas Padjadjaran-Rumah Sakit Umum Dr. Hasan Sadikin \\ *** Departemen Patologi Anatomi \\ Fakultas Kedokteran Universitas Padjadjaran-Rumah Sakit Umum Dr. Hasan Sadikin \\ J1. Prof.Eyckman No. 38, Bandung, 40161 \\ Email: sarah.anjaniputri@gmail.com
}

\begin{abstract}
Abstrak
Karsinoma laring adalah keganasan yang berasal dari jaringan sel epitel skuamosa laring. Faktor risiko karsinoma laring antara lain adalah, umur, jenis kelamin, merokok, konsumsi alkohol, gastroesophangeal reflux disease (GERD)/ laryngopharyngeal reflux (LPR). Berkaitan dengan hal tersebut, dilakukan penelitian untuk mengetahui faktor risiko karsinoma laring di Rumah Sakit Dr. Hasan Sadikin Bandung. Metode penelitian menggunakan desain studi kasus kontrol unmatched melibatkan 80 pasien Poli Onkologi Ilmu Kesehatan THT-KL RSHS Bandung bulan Januari 2016 sampai Mei 2017. Hasilnya adalah persentase usia 50-79 tahun dengan karsinoma laring terbanyak dengan 82,5\% dengan $\mathrm{OR}=7,29$. Responden laki-laki dengan karsinoma laring adalah sebanyak $90 \%$ dengan meningkatkan risiko karsinoma laring sebanyak 6 kali. Kelompok kasus dengan GERD ada sebanyak 45\% dan meningkatkan risiko karsinoma laring sebanyak 15,54 kali. Hasil ini signifikan karena $\mathrm{p}<0,005$. Sedangkan, faktor risiko riwayat keluarga, merokok, dan konsumsi alkohol tidak dinyatakan signifikan secara statistik karena nilai $p>0,005$. Hasil penelitian tentang usia, jenis kelamin, dan GERD/LPR sesuai dengan penelitian sebelumnya. Sedangkan, hasil untuk rokok, alkohol, dan riwayat keluarga tidak sesuai. Dari penelitian ini disimpulkan usia lanjut, jenis kelamin laki-laki, dan GERD/LPR meningkatkan risiko terjadinya karsinoma laring.
\end{abstract}

Kata kunci: faktor risiko, karsinoma laringeal 
Research Article

\section{Introduction}

Laryngeal carcinoma is a malignancy of squamous cells on laryngeal epithelial layer and divided into supraglottic, subglottic, and glottic malignancy. ${ }^{1}$ It is the most common head and neck cancer in the world with the incidence 3.2 per 100,000 person per year in the world. ${ }^{2}$ Indonesian incidence of laryngeal carcinoma is 2.0 per 100,000 men and 0.2 per 100,000 women. ${ }^{3}$ The number of laryngeal carcinoma patients in Dr. Hasan Sadikin General Hospital, Bandung within 2011-2016 is 426 cases, based on the hospital's medical records.

The exact etiology of laryngeal carcinoma is yet to be determined, but there are several risk factors associated with it. ${ }^{4}$ The risk factors are lifestyle related behavior such as, smoking and alcohol drinking, or other risks such as family history, genetic, age, sex, and certain disease like gastroesophangeal reflux disease (GERD) or laryngopharyngeal reflux (LPR). ${ }^{5,6}$ Laryngeal carcinoma is the third highest malignancy found in the Otolaryngology, Head, and Neck Department of Dr. Hasan Sadikin General Hospital, Bandung. The outcome of this disease can lower the patient's quality of live to the extent of speaking inability, dysphagia, and difficulty in breathing. ${ }^{7}$ Based on these regards, this study is conducted to measure the risk factor of laryngeal carcinoma in Dr. Hasan Sadikin General Hospital, Bandung.

\section{Methods}

Hospital-based unmatched case control study design were used in this research. Data collection was started by obtaining the outcome or dependent variable, the case group, which was laryngeal carcinoma patients in the Oncology Clinic of Otorhinolaryngology-Head and Neck Department Dr. Hasan Sadikin General Hospital, Bandung diagnosed based on histopathology result; and control group, the patient of other malignancy beside laryngeal carcinoma presented in Oncology Clinic of Otorhinolaryngology Head and Neck Department of Dr. Hasan Sadikin General Hospital, Bandung. This study was done using randomly taken secondary data from the hospital's medical records, which include the information of patients' age, sex, family history, smoking history, alcohol consumption, and GERD/LPR history. In this study, the amount of alcohol was not included, only whether the patient had drunken alcohol before or not. This study has been approved by Faculty of Medicine, Universitas Padjadjaran and Dr. Hasan Sadikin General Hospital ethical committee.

Unpaired comparative analysis formula was used to calculate sample size with alpha standard deviation $Z \alpha=1.96$ and beta standard deviation $Z \beta=0.84$; value of $\mathrm{P} 1=0.79$ and $\mathrm{P} 2=$ 0.49 ; thus, sample size was calculated as 40 for each case and control group, or 80 people in total. Non-probability consecutive sampling was done to select sample; patient's medical record in Oncology Clinic of Otorhinolaryngology-Head and Neck Surgery Department Dr. Hasan 


\section{Research Article}

Sadikin General Hospital, Bandung within January 2016 to May 2017 were appointed as samples on this study. Collected data were selected based on the inclusion criteria, which was laryngeal carcinoma patient diagnosed based on histopathology result; and the exclusion criteria, which was patients with multiple malignancies and incomplete medical records.

Chi square was used to test different unpaired categorical variable. Significance of the test result was determined by $p$ value, should the $p \leq 0.005$ the result was considered significant. Excess risk was measured by calculating odds ratio (OR) and confidence interval (CI) $95 \%$.

\section{Results}

There were 88 data obtained using non probability consecutive sampling technique where all the accessible subjects were chosen. Among the 88 data, 8 were excluded due to incomplete data. From the remaining data, there were 40 data for each case and control group, thus made total 80 data.

On this research in terms of age, most case group respondents were 50- 79 years old $(82.5 \%)$ while in the control group it was $<50$ years old patients composing $52.5 \%$ (Table 1). The table was tested by using logistic regression and acquired the $\mathrm{p}$ value of 0.001 . Odds ratio of the age groups was 2.45 .

In terms of sex, most respondents were male composing $90 \%$ and $60 \%$ for the case and control group respectively (Table 1). Chi square test was used to test the table and the result was $\mathrm{p}=0.002$ indicating the significance of sex in this study with the odds ratio of 6.00 with $95 \% \mathrm{CI}$ 1.78-20.14. This result showed that males has 6 times more risk to develop laryngeal carcinoma than females.

Based on smoking history of the patients, most of the case group (55\%) and the control group (75\%) didn't smoke (Table 1). After Chi square test, the difference is not significant statistically with $\mathrm{p}=0.061$. The case and control group shows more respondents didn't have any family history of laryngeal carcinoma. Chi square test was done and resulting $p=0.745$, therefore, the result is not significant statistically. In terms of smoking, most of the case group (55\%) and control group (75\%) didn't have smoking history. After using Chi square test, the result was $\mathrm{p}=0.061$, so this has no significance statistically. Meanwhile, based on alcohol consumption, only $15 \%$ of the case group and $5 \%$ of the control group consumed alcohol. This variable's table is not feasible to be tested with Chi Square test, because it has cell with expected value less than five 50\% of the cell number. Therefore, Fisher Exact test was used and the result acquired was $\mathrm{p}=0.132$ so it has no significance statistically.

There were 18 respondents $(45 \%)$ in the case group and 2 respondents $(5 \%)$ in the control group that was diagnosed GERD (Table 1). Chi square test results show $\mathrm{p}=0.000$, 


\section{Research Article}

indicating its significance statistically. The odds ratio was 15.54 with 95\%CI 3.29-73.4. The result means GERD patient has 15.54 times higher risk of having laryngeal carcinoma than the patient with no GERD.

Tabel 1 Risk Factors of Laryngeal Carcinoma

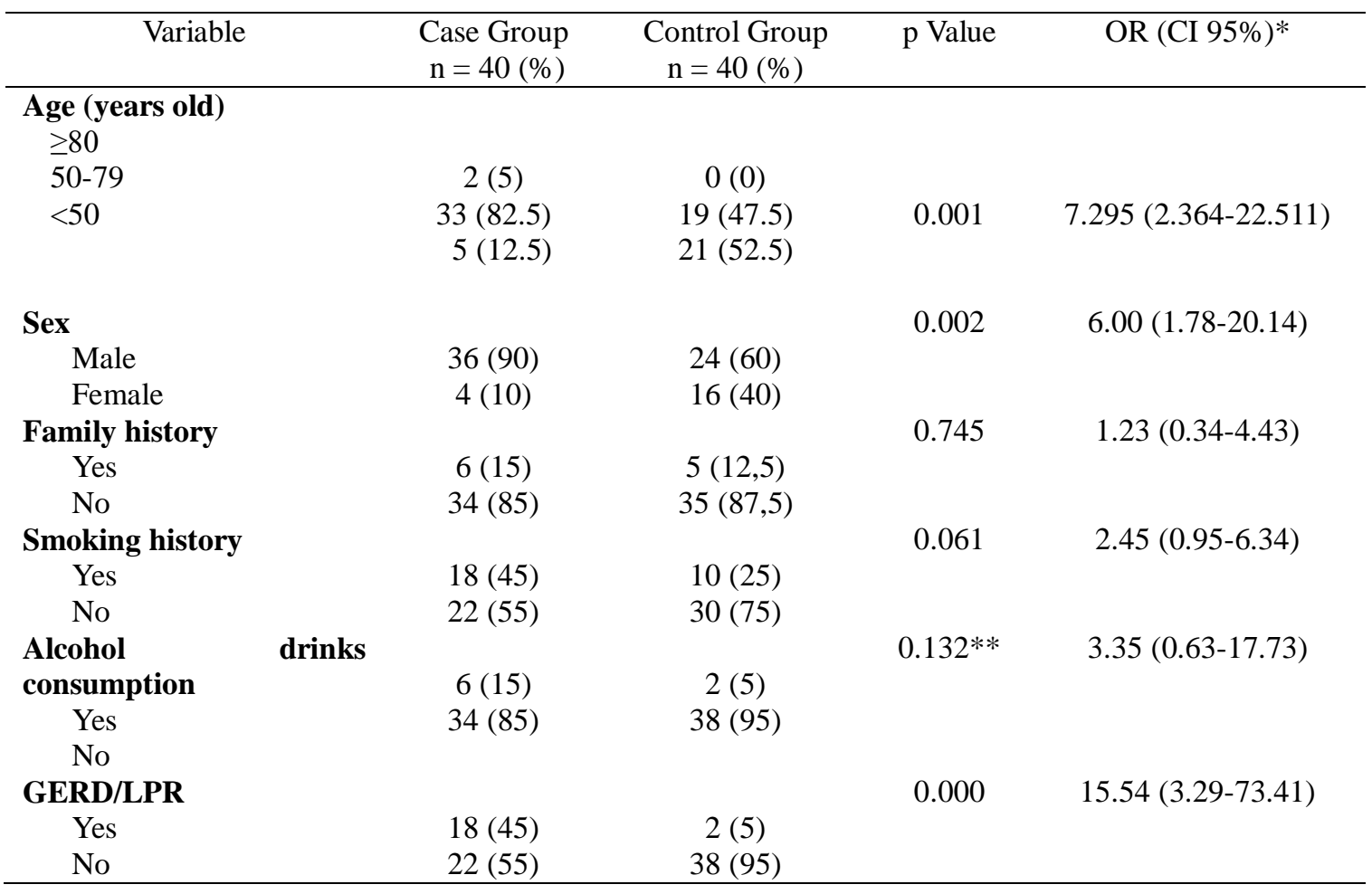

*) OR (CI 95\%): Odds Ratio (Confidence Interval 95\%)

**) Used Fisher Exact Test

\section{Discussion}

This study analyzes some of the risk factor for laryngeal carcinoma in Dr. Hasan Sadikin General Hospital Bandung. In terms of age, it showed associated between age and laryngeal carcinoma with $\mathrm{p}=0.001$. The result showed a higher risk for an old aged patient to have laryngeal carcinoma, this was corresponded with a study of Cancer Research UK and Surveillance, Epidemiology, and End Results Program that stated 30.9\% of laryngeal carcinoma patient aged 55-64 years old. ${ }^{2,8}$ Malignancy in elderlies may be caused by mutation accumulating inside the body, making the deoxyribonucleic acid repairing process less efficient, decreasing function of immune system that makes the defend against cancerous cell decreasing. ${ }^{9}$ Moreover, it can also be the results of cellular senescence which accumulate with the older age and supporting microenvironment of cancerous cell development. ${ }^{10}$ 


\section{Research Article}

The result of the study acquired that sex and laryngeal carcinoma are associated and showed significance of $p=0.002$. The study showed that males have 6 times more risk to have laryngeal carcinoma than females. This suited a study that stated the ratio of male:female in laryngeal carcinoma was 7:1. ${ }^{3}$ This higher risk for males could be the result of their lifestyle and their lack of awareness in diseases. ${ }^{11}$

Study result about association of GERD and laryngeal carcinoma revealed a significant result statistically. Statistical test showed $\mathrm{p}=0.000$ and a 15.54 times higher risk for a GERD patient to have laryngeal carcinoma. The result of the study is parallel with previous study that stated the fluid could've been refluxed to the respiratory tract and damage its epithelium by inducing chronic inflammation, reactive oxygen species and nitrogen production, intracellular acidification, and proliferative signal pathway activation that will transform into malignancy of the cells. ${ }^{12}$

This study showed that family history, smoking history, and alcohol consumption did not have association with laryngeal carcinoma, because $p>0.005$. This was not corresponded with previous study which stated that family history that correlated with genetic factor increase the risk of laryngeal carcinoma. ${ }^{12}$ Whereas, this study did not include any comprehensive genetic testing. Previous study showed that tobacco smoking was the main risk factors of laryngeal carcinoma because of the carcinogenic nicotine of tobacco. ${ }^{14,15}$ Therefore, tobacco smoking is a general risk factor of any malignancy, and it could affect the results of this study. Based on the previous study, alcohol caused acetaldehyde polymorphism that can develop into malignancy. ${ }^{14}$ The results may have been like this because of the no alcohol drinks habit in Indonesia, especially West Java generally.

The limitations of this study was the incomplete data and lack of practical archiving of medical record in Dr. Hasan Sadikin General Hospital Bandung and some variable overlapped with other malignancies' risk factor. Besides that, time shortage is other limitation of the study.

\section{Conclusion}

This study showed that old age, male sex, and GERD increase the risk of having laryngeal carcinoma. The highest risk is GERD/LPR and the lowest one is patients with old age. Advice for this study is to conduct a more detailed and comprehensive study to consider confounding factors that may affect the study results.

\section{References}

1. Williamson JS, Biggs TC, Ingrams D. Laryngeal cancer: an overview. World J Mens Health. 2012;3(6):14-7.

2. Surveillance E, and End Results Program. SEER Stat Fact Sheets: Laryngeal Cancer. USA: National Cancer Institute; 2013 [cited 20175 January 2017]; Available from: https://seer.cancer.gov/statfacts/html/laryn.html. 


\section{Research Article}

3. Ferlay J, Soerjomataram I, Dikshit R, Eser S, Mathers C, Rebelo M, et al. Cancer incidence and mortality worldwide: sources, methods and major patterns in GLOBOCAN 2012. Int J Cancer. 2015;136(5):E359-E86.

4. Kementerian Kesehatan R. Laporan Hasil Riset Kesehatan Dasar (Riskesdas) 2013. Jakarta: Kementerian Kesehatan RIDinKes Jateng; 2013. p. 85-6.

5. Langevin SM, Michaud DS, Marsit CJ, Nelson HH, Birnbaum AE, Eliot M, et al. Gastric reflux is an independent risk factor for laryngopharyngeal carcinoma. Cancer Epidemiol Biomarkers Prev. 2013;22(6):1061-8.

6. Stephen JK, Chen KM, Shah V, Havard S, Lu M, Schweitzer VP, et al. Human papillomavirus outcomes in an access-to-care laryngeal cancer cohort. Otolaryngol Head Neck Surg. 2012;146(5):730-8.

7. Marioni G, Marchese-Ragona R, Cartei G, Marchese F, Staffieri A. Current opinion in diagnosis and treatment of laryngeal carcinoma. Cancer Treat. Rev. 2006;32(7):504-15.

8. UK CR. Laryngeal Cancer Risk Factors. Angel Building, 407 St John Street, London EC1V 4AD: Cancer Research UK; 2014 [updated 19 December 2014; cited 201711 January]; Available from: http://www.cancerresearchuk.org/health-professional/cancer-statistics/statistics-by-cancer-type/laryngealcancer/risk-factors\#heading-One.

9. Gugi'c J, Strojan P. Squamous Cell Carcinoma of the Head and Neck in the Elderly. Rep Pract Oncol Radiother. $2013 ; 16-15$

10. Campisi J. Aging, Cellular Senescence, and Cancer. Annu Rev Phys. 2013:75

11. team TACSmaec. Risk Factors for Laryngeal and Hypopharyngeal Cancer. American Cancer Society; 2016 [updated 8 Agustus 2016; cited 20171 Maret]; Available from: https://www.cancer.org/cancer/laryngeal-andhypopharyngeal-cancer/causes-risks-prevention/risk-factors.html\#written_by.

12. Deganello A, Meccarello G, Parrinello G, Gallo O. Laryngopharyngeal Reflux and Laryngeal Squamous Cell Carcinoma. Austin J Canc Clin Res. 2015:1.

13. Turati F, Negri E, Vecchia CL. Family history and the risk of cancer: genetic factors influencing multiple cancer sites. Expert Rev Anticancer Ther. 2014;14(1):1-4.

14. Anantharaman D, Marron M, Lagiou P, Samoli E, Ahrens W, Pohlabeln H, et al. Population attributable risk of tobacco and alcohol for upper aerodigestive tract cancer. Oral Oncol. 2011;47(8):725-31.

15. Centers for Disease Control and Prevention (US). How tobacco smoke causes disease: the biology and behavioral basis for smoking-attributable disease: a report of the surgeon general. 2010. [cited 20175 January 2017]; Available from: https://www.ncbi.nlm.nih.gov/pubmed/21452462 